\title{
A CD25- positive population of activated B1 cells expresses LIFR and responds to LIF
}

\author{
Joseph R. Tumang ${ }^{\dagger}$, Nichol E. Holodick, Teresa C. Vizconde, Hiroaki Kaku, Rubén Francés ${ }^{\dagger}$ and \\ Thomas L. Rothstein*
}

Immunobiology Laboratory, Center for Oncology and Cell Biology, The Feinstein Institute for Medical Research, Manhasset, NY, USA

\author{
Edited by: \\ Tim L. Manser, Thomas Jefferson \\ University, USA \\ Reviewed by: \\ Kishore Alugupalli, Thomas Jefferson \\ University, USA \\ Tim L. Manser, Thomas Jefferson \\ University, USA

\section{*Correspondence:} \\ Thomas L. Rothstein, The Feinstein \\ Institute for Medical Research, 350 \\ Community Drive, Manhasset, NY \\ 11030, USA. \\ e-mail: tr@nshs.edu \\ 'Present address: \\ Joseph R. Tumang, EMD Serono \\ Research Center, 45 Middlesex \\ Turnpike, Billerica, MA, USA; \\ Rubén Francés, CIBERehd-Liver Unit, \\ Hospital General Universitario de \\ Alicante, Pintor Baza 12, 03010 \\ Alicante, Spain.
}

B1 B cells defend against infectious microorganisms by spontaneous secretion of broadly reactive "natural" immunoglobulin that appears in the absence of immunization. Among many distinguishing characteristics, B1 B cells display evidence of activation that includes phosphorylated STAT3. In order to identify the origin of pSTAT3 we examined interleukin-2 receptor (IL-2R) expression on B1 cells. We found that some (about 1/5) B1a cells express the IL-2R $\alpha$ chain, CD25. Although lacking CD122 and unresponsive to IL-2, B1a cells marked by CD25 express increased levels of activated signaling intermediates, interruption of which results in diminished CD25. Further, CD25+ $\mathrm{B} 1$ a cells contain most of the pSTAT3 found in the B1a population as a whole. Moreover, $\mathrm{CD} 25^{+} \mathrm{B} 1$ a cells express leukemia inhibitory factor receptor (LIFR), and respond to LIF by upregulating pSTAT3. Together, these results define a new subset of B1a cells that is marked by activation-dependent CD25 expression, expresses substantial amounts of activated STAT3, and contains a functional LIFR.

Keywords: B1 cells, CD25, LIF receptor, signaling

\section{INTRODUCTION}

In mice, B1 cells represent a unique subset of B lymphocytes originally distinguished from the more abundant conventional splenic $\mathrm{B}$ cells by expression of the pan-T cell marker, CD5. In addition to CD5, other phenotypic characteristics that identify B1 cells include $\mathrm{sIgM}^{\mathrm{hi}}$, $\mathrm{sIgD}^{\mathrm{lo}}, \mathrm{CD}^{2} 3^{-}$, and $\mathrm{CD} 43^{+}$(reviewed in Hardy and Hayakawa, 2001; Wortis and Berland, 2001; Berland and Wortis, 2002; Rothstein, 2002). During development, B1 cells appear first after which B2 cell production proceeds while relative B1 cell numbers decline (Hayakawa et al., 1983; Lalor et al., 1989; Hamilton et al., 1994). In adult mice, B1 cells are the predominant lymphocyte population in the peritoneal and pleural cavities, are present in small numbers in the spleen, and are absent in the peripheral blood and lymph nodes (Hayakawa et al., 1983). B1 B cells are capable of self-renewal, giving rise to their own progeny, in contrast to B2 cells which are continually generated in the bone marrow from stem cell precursors (Hayakawa et al., 1986; Kantor et al., 1995), although recently it has been suggested that the B1 cell pool in adult animals admits bone marrow-derived emigrants over time (Duber et al., 2009; Holodick et al., 2009a). Two B1 cell populations exist, $\mathrm{B} 1 \mathrm{a}$ cells that express $\mathrm{CD} 5$, and $\mathrm{B} 1 \mathrm{~b}$ cells that lack CD5 but are otherwise phenotypically similar to B1a cells although in some ways functionally distinct (Kantor et al., 1992; Alugupalli et al., 2004). Much of what is known about B1 cells concerns $\mathrm{CD}^{+}{ }^{+} \mathrm{B} 1 \mathrm{a}$ cells.

Abbreviations: IMGT, ImMunoGeneTics; LIF, leukemia inhibitory factor; LIFR, LIF receptor; PLC, phospholipase C; Syk, spleen tyrosine kinase.
B1 cells contribute to immune protection through spontaneous production of "natural" immunoglobulin that is generated in the absence of specific immunization and accounts for most of the "resting" IgM and a substantial portion of the "resting" IgA found in the serum. B1 cell-derived natural immunoglobulin is critically important in the early defense against, and clearance of, bacterial and viral infections (Briles et al., 1981; Su et al., 1991; Boes et al., 1998; Benedict and Kearney, 1999; Ochsenbein et al., 1999; Baumgarth et al., 2000; Alugupalli et al., 2004). Natural immunoglobulin differs from B2 cell-derived immunoglobulin in being more germline like - as a result of minimal N-region addition and somatic hypermutation - and is repertoire-skewed reflecting antigen-driven selection (Hardy et al., 1989; Pennell et al., 1989; Gu et al., 1990). The rules governing immunoglobulin production by $\mathrm{B} 1$ cells appear to differ from those that regulate immunoglobulin production by $\mathrm{B} 2$ cells, in that $\mathrm{B} 1$ cell immunoglobulin secretion is much less dependent on Blimp-1 and IRF4 than is that of B2 cells, although a role for Blimp-1 in B1 cell immunoglobulin secretion has been suggested (references Lin et al., 2003; Tumang et al., 2005; Klein et al., 2006; Savitsky and Calame, 2006; Holodick et al., 2010).

Aside from constitutive immunoglobulin secretion, B1 cells manifest a number of distinctive features. In comparison to B2 cells, they present antigen more efficiently and unlike B2 cells, they induce naïve CD4 T cells to become Th17 cells (Zhong et al., 2007a,b). Moreover, B1 cells respond mitogenically to phorbol ester in the absence of a calcium ionophore whereas B2 cells do not, and in contrast to B2 cells, B1 cells fail to proliferate, nor to 
activate $\mathrm{NF}-\kappa \mathrm{B}$, in response to BCR engagement (Rothstein and Kolber, 1988a, 1988b; Morris and Rothstein, 1993). The unique mitogen responses of $\mathrm{B} 1$ cells are reflected in distinct alterations of cyclins D2 and D3 (Tanguay et al., 1999, 2001).

Beyond these functional characteristics, the nature of $\mathrm{B} 1$ cells remains uncertain. B1 cells express a number of genes, proteins, and transcription factors differently than B2 cells (Fischer et al., 2001; Wong et al., 2002; Frances et al., 2006, 2007). This fits with the idea that B1 cells represent a separate B cell lineage, a notion supported by the recent identification of a distinct B220 ${ }^{\mathrm{lo} /-} \mathrm{CD} 19^{+}$ B1 cell progenitor (Herzenberg, 2000; Montecino-Rodriguez et al., 2006). On the other hand, B1 cells appear to develop in relation to the strength and nature of BCR signaling (Arnold et al., 1994; Casola et al., 2004; Hardy, 2006). This fits with the idea that B1 cells represent a particular differentiation state of a single B cell lineage (Cong et al., 1991; Wang and Clarke, 2004). The finding that B1 cells show evidence of prior or ongoing activation, such as CD44 expression and elevated baseline pERK (Murphy et al., 1990; Wong et al., 2002), would seem to support the latter notion, and we have concluded in other work that B1 cells experience continual signaling (Holodick et al., 2009b). On the other hand, B1 cells lack some facets of activation, such as CD69 expression or elevated baseline nuclear NF- $\kappa$ B or c-myc expression (Morris and Rothstein, 1993; Wang et al., 1995; Tumang et al., 2004). Particularly perplexing has been the constitutive expression by $\mathrm{B} 1$ cells of activated, tyrosine phosphorylated STAT3 (Karras et al., 1997).

CD25 [interleukin-2 receptor (IL-2R) $\alpha$ chain] is a $55-\mathrm{kDa}$ glycoprotein, which along with CD122 ( $\beta$ chain) and CD132 (common $\gamma$-chain) forms the high affinity receptor for IL-2 (Minami et al., 1993). In B cells, CD25 expression is first detected during the pre-B cell stage of development after which expression declines as newly formed B cells migrate to the spleen to form the mature B2 cell compartment (Rolink et al., 1994). In mature B2 cells, CD25 is re-expressed as an activation marker in response to antigenic encounter in an NF- $\kappa \mathrm{B} / \mathrm{c}$-Rel dependent manner (Muraguchi et al., 1985; Tumang et al., 1998).

Interleukin-2 receptor signaling has been shown to induce phosphorylation and activation of STAT3 (Nielsen et al., 1994; Brunn et al., 1995; Frank et al., 1995). In order to elucidate the origin of pSTAT3 in B1a cells, and in view of our finding that $\mathrm{B} 1$ cells show evidence of continual signaling, we considered the possibility that B1 cells might express CD25/IL-2R and that IL-2R signaling might account for B1 cell activated STAT3. In fact, we did find that some, but not all, B1 cells express CD25, although not as a complete, IL-2-responsive receptor. We further found that CD25 expression divides $\mathrm{B} 1$ cells into two populations, one of which $\left(\mathrm{CD} 25^{+}\right)$contains pSTAT3 and activated signaling intermediates, expresses leukemia inhibitory factor receptor (LIFR), and responds to LIF, whereas the other $\left(\mathrm{CD} 25^{-}\right)$for the most part does not.

\section{MATERIALS AND METHODS \\ ANIMALS}

Male BALB/cByJ, C57BL/6, and C.B17-Prkdc scid mice at 814 weeks of age were obtained from The Jackson Laboratory. All experiments were approved by the Institutional Animal Care and Use Committee, and mice were cared for and handled in accordance with National Institutes of Health and institutional guidelines.

\section{B CELL PURIFICATION AND CULTURE}

Sort-purified peritoneal B1 were obtained on the basis of CD5 and B220 staining $\left(\mathrm{CD}^{+} \mathrm{B} 220^{\mathrm{lo}}\right)$. Splenic follicular (FO) B2 and marginal zone (MZ) B2 cells were obtained on the basis of CD23 and CD21 expression. Splenic T cells were obtained on the basis of CD5 and B220 staining $\left(\mathrm{CD}^{+} \mathrm{B}^{-220^{-}}\right)$. Sort-purified B1 cells were further subdivided on the basis of CD25 expression. Populations were reanalyzed for purity by flow cytometry and subsets determined to be $>98 \%$ pure. Sort-purified B cells were cultured in RPMI 1640 containing $10 \%$ heat-inactivated fetal bovine serum, $2 \mathrm{mM}$ L-glutamine, $50 \mu \mathrm{M}$ 2-mercaptoethanol, $100 \mathrm{U} / \mathrm{ml}$ penicillin, and $100 \mu \mathrm{g} / \mathrm{ml}$ streptomycin.

\section{GENE EXPRESSION}

RNA was prepared from B cells using Ultraspec reagent (BiotecX), was DNase treated, and was reverse transcribed using iScript (BioRad). Gene expression was then assessed by real-time PCR (Stratagene) using the following primers (forward/reverse): $\beta_{2}$-microglobulin (CCCGCCTCACA TTGAAATCC/GCGTATGTATCAGTCTCAGTGG); LIFR;ATGGC ACATTGACTCGCCTC/GCACGAAGGGTATTGCCGAT), SOCS3 (CCCGCTTCGACTGTGTACTCA / GAGGTCGGCTCAGTACCA GC), and CD122 (CACAGGCCAGCTGCTTCAC/AGGCATTGGG CAGATGGAA).

\section{PROTEIN EXPRESSION}

Sort-purified cells were extracted and extracted proteins were immunoblotted as previously described (Tumang et al., 2005). Membranes were developed using the ECL Western Blotting Analysis System from Amersham Biosciences. As a protein loading control, blots were stripped and reprobed with anti-actin Ab.

\section{PHOSPHOFLOW ANALYSIS}

Intracellular phosphospecific flow cytometry and fluorescent cell barcoding were carried out as previously described (Holodick et al., 2009b). Flow cytometric analysis was performed using a BD Biosciences LSR II.

\section{REAGENTS}

Fluorescently labeled anti-B220, anti-CD5, anti-CD23, antiCD21, anti-CD69, and anti-CD25 (clone PC61) antibodies for flow cytometry and cell sorting were obtained from BD Biosciences. $\mathrm{F}\left(\mathrm{ab}^{\prime}\right)_{2}$ fragments of goat anti-mouse IgM for $B$ cell stimulation in vitro were obtained from Jackson Immunoresearch. Recombinant LIF and IL-6 for B cell stimulation in vitro were obtained from R\&D Systems. LY294002 and Syk inhibitor [(3-(1-Methyl-1H-indol-3-yl-methylene)-2oxo-2,3-dihydro- $1 \mathrm{H}$-indole-5-sulfonamide] were obtained from Calbiochem. Antibodies directed against tyrosine phosphorylated (705) STAT3 and STAT3 for immunoblotting were obtained from Cell Signaling Technology. Fluorescent antibodies directed against tyrosine phosphorylated Syk, PLC $\gamma 2$, and STAT3 for phosphoflow analysis were obtained from BD Biosciences. Anti-LIFR antibody for immunoblotting was obtained from Santa Cruz Biotechnology. Anti-actin antibody was obtained from Sigma-Aldrich. 

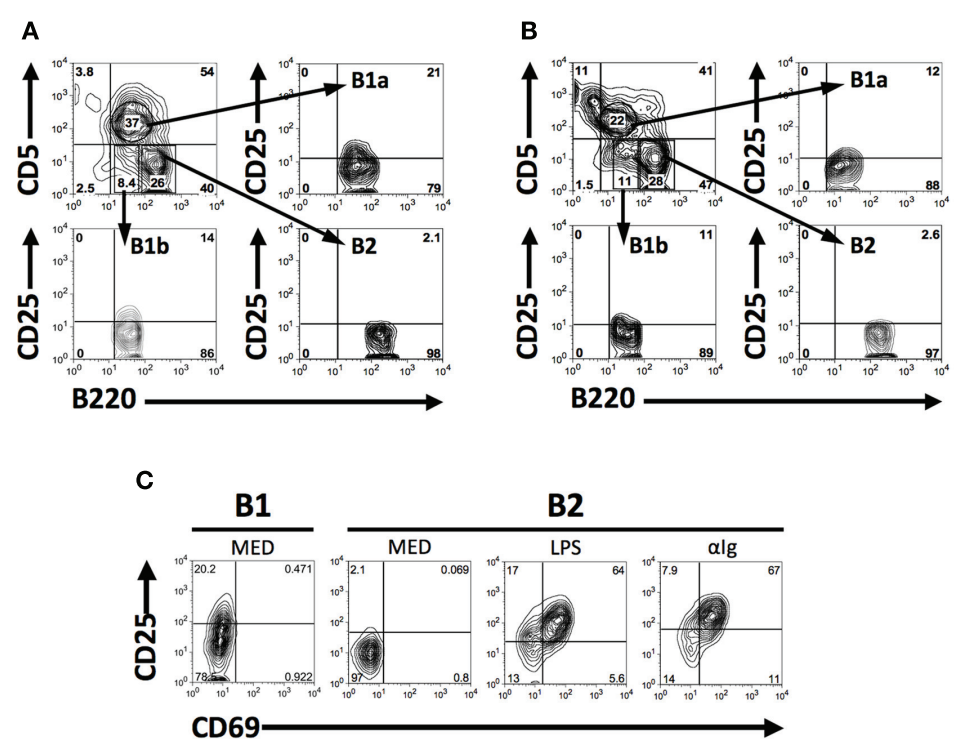

FIGURE 1 | CD25 is expressed on a subset of naïve peritoneal $B 1$ cells. $(\mathbf{A}, \mathbf{B})$ Freshly isolated BALB/C (A) and C57BL/6 (B) peritoneal washout cells were immunofluorescently stained for surface expression of B220, CD5, and $\mathrm{CD} 25$. Gates were set to identify B1a $\left(\mathrm{B} 220^{\circ}, \mathrm{CD}^{+}\right), \mathrm{B} 1 \mathrm{~b}\left(\mathrm{~B} 220^{\circ}, \mathrm{CD}^{-}\right)$, and $\mathrm{B} 2\left(\mathrm{~B}_{220^{+}}, \mathrm{CD}^{-}\right)$cells among B220 $\mathrm{B}$ cells and expression of $\mathrm{CD} 25$ was assessed for each population. Representative results from one of seven (A) and three (B) comparable experiments are shown. (C) Freshly isolated

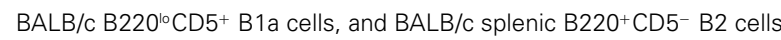
cultured in medium (MED) or stimulated with LPS $(25 \mu \mathrm{g} / \mathrm{ml})$ or with $\mathrm{F}\left(a b^{\prime}\right)_{2}$ fragments of goat anti-mouse IgM $(15 \mu \mathrm{g} / \mathrm{ml})$ for 2 days, were immunofluorescently stained for CD25 and CD69. CD25 mean fluorescence intensity values (above background isotype staining) for $\mathrm{CD}_{2} 5^{+} \mathrm{B} 1 \mathrm{a}$ cells and for $\mathrm{CD} 25^{+} \mathrm{CD} 69^{+} \mathrm{B} 2$ cells after stimulation with LPS and anti-lg were, respectively, 53, 123, and 189. One of three comparable experiments is shown.

\section{RESULTS}

\section{CD25 IS EXPRESSED ON A SUBSET OF NAÏVE PERITONEAL B1 CELLS}

CD25 is expressed on B2 cells as an activation marker (Tumang et al., 1998), and naïve B1 cells show evidence of continual activation (Holodick et al., 2009b), which together raise the possibility that B1 cells might constitutively express CD25. To determine whether B1 cells express CD25, we analyzed B cell populations by flow cytometry following immunofluorescent staining. Results are shown in Figure 1. We found that some (about 1/5), but not all, naïve BALB/c peritoneal B1 (B1a) cells expressed CD25, as did a smaller number of B1b cells (about 1/10). In contrast, few if any splenic B2 cells (data not shown) or peritoneal B2 cells (Figure 1A) expressed CD25. B1a cell expression of CD25 was not limited to BALB/c mice, as some, albeit fewer, C57BL/6 B1a cells also expressed CD25 in contrast to C57BL/6 B2 cells (Figure 1B). Thus, CD25 expression divides B1 cells into two separate populations. We compared the level of CD25 expression on $\mathrm{BALB} / \mathrm{c}$ peritoneal B1a cells with the level of expression on splenic B2 cells after stimulation by LPS or anti-Ig for 2 days. Results are shown in Figure 1C. We found that CD25 expression by $\mathrm{CD}^{+} 5^{+}\left(\mathrm{CD}^{-} 9^{-}\right)$peritoneal B1a cells encompassed a range similar to that of $\mathrm{CD} 25^{+} \mathrm{CD} 69^{+}$splenic $\mathrm{B} 2$ cells, although the mean fluorescence intensity of the latter outweighed the former.

\section{CD25 EXPRESSION BY B1a CELLS IS ASSOCIATED WITH, AND DEPENDS ON, ACTIVATED SIGNALING INTERMEDIATES}

The finding that some Bla cells do, and other B1a cells do not, express the activation-related marker, CD25, raises the possibility that $\mathrm{CD} 25^{+}$B1a cells are signaling more intensely than
CD25- B1a cells. To address this issue, we examined the phosphorylation status of BCR-triggered signaling intermediates in sort-purified B cell populations by phosphoflow analysis, utilizing barcoding after fixation and permeabilization to facilitate experimentation (Krutzik and Nolan, 2006). To enhance detection of phosphorylated intermediates, we added sodium orthovanadate to unstimulated B cells for 1 or $2 \mathrm{~min}$, to block dephosphorylation (Holodick et al., 2009b). Results are shown in Figure 2A. We found that B1a cells accumulated substantial amounts of intracellular pSyk and pPLC $\gamma 2$ after exposure to sodium orthovanadate for $2 \mathrm{~min}$, whereas B2 cells showed a much smaller increase, as previously reported (Holodick et al., 2009b). Importantly, within the B1a population, CD25 ${ }^{+}$B1a cells showed evidence of much more pSyk and pPLC $\gamma 2$ than did $\mathrm{CD}_{2} 5^{-} \mathrm{B} 1 \mathrm{a}$ cells. The same patterns held true when $\mathrm{B}$ cells were stimulated by anti-IgM (in the absence of $\mathrm{Na}_{3} \mathrm{VO}_{4}$ ). Here again B1a cells increased pSyk and pPLC $\gamma 2$ to higher levels than did B2 cells, and $\mathrm{CD} 25^{+}$B1a cells were more responsive than $\mathrm{CD} 25^{-}$B1a cells. Thus, CD25 expression marks a B1a subset that is more active in terms of constitutive, ongoing phosphorylation of signaling intermediates, and is more responsive in terms of BCR-triggered signaling.

The elevated level of phosphorylated signaling intermediates in B1a cells that express the activation-related marker, CD25, suggests the possibility that B1a CD25 expression depends on enhanced signaling. To address this possibility, we examined sort-purified Bla cells for CD25 expression before and after inhibition of PI-3K by treatment with LY294002 and inhibition of Syk by treatment with a peptide Syk inhibitor, for $18 \mathrm{~h}$. Over this period of time these inhibitors do not affect B cell viability (Holodick et al., 2009b). 


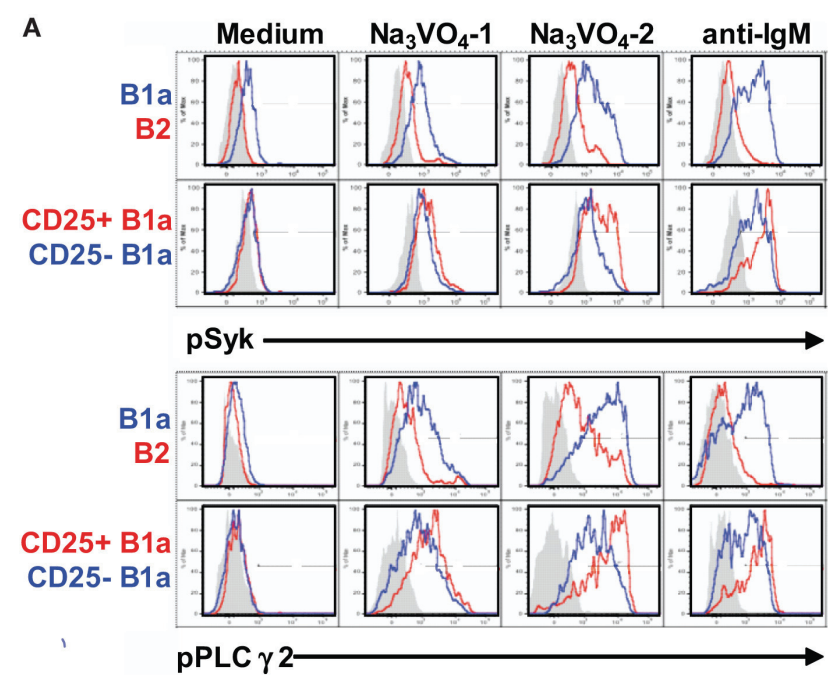

B

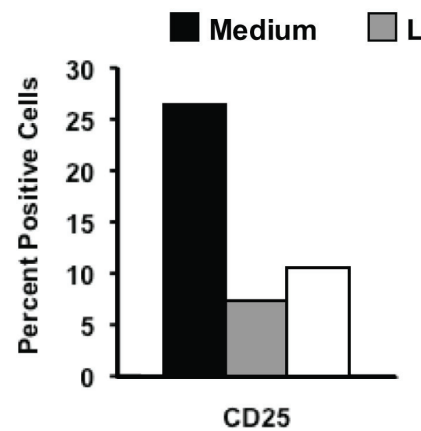

FIGURE 2 | CD25 expression by B1a cells is associated with, and depends on, activated signaling intermediates. (A) Four populations of $B$ cells were sort-purified: peritoneal B1a cells ("B1a" in blue in upper panels), splenic follicular B2 cells ("B2" in red in upper panels), CD25+ peritoneal B1a cells ("CD25+ B1a" in red in lower panels), and CD25- peritoneal B1a cells ("CD25- B1a" in blue in lower panels). B cells were cultured in medium alone ("Medium"), and with $\mathrm{Na}_{3} \mathrm{VO}_{4}$ at $10 \mathrm{mM}$ for 1 or $2 \mathrm{~min}$, as indicated, or with $F(a b /)_{2}$ fragments of goat anti-mouse $\operatorname{lgM}$ at $15 \mu \mathrm{g} / \mathrm{ml}$ for 4 min ("anti-lgM"). Cells were then harvested, fixed, permeabilized, and

Results are shown in Figure 2B. We found that interference with PI-3K or with Syk substantially abrogated CD25 expression by Bla cells. In contrast, and as a control, inhibition of neither PI-3K nor Syk produced a reduction in expression of the $\mathrm{B} 7$ molecule CD80. Thus, B1a expression of CD25 is specifically dependent on enhanced activation of signaling intermediates.

\section{CD25+ B1a CELLS DISPLAY ELEVATED LEVELS OF PHOSPHORYLATED TYROSINE705 STAT3}

Because IL-2 is capable of activating STAT3, CD25 expression by some B1a cells raises the possibility that the $\mathrm{CD} 25^{+} \mathrm{B} 1 \mathrm{a}$ subset harbors all of the constitutively phosphorylated STAT3 attributed to B1 cells as a whole (Karras et al., 1997). To address this possibility, we examined sort-purified lymphocyte populations by Western blotting for the activated form of STAT3 (pTyr705STAT3). Results are shown in Figure 3A. We found that, as previously described, peritoneal B1 cell lysates contained pTyr705STAT3 whereas splenic B2 and T cell lysates did not. Importantly, we found that among B1a cells, the large majority of pTyr705STAT3 was located specifically within the $\mathrm{CD} 25^{+}$B1a fraction. To verify the relative enrichment of CD25 ${ }^{+}$B1a cells for pTyr705STAT3 we examined expression of the STAT3-regulated gene, SOCS3, by real-time PCR amplification of reverse-transcribed RNA obtained from sortpurified B cell populations. Results are shown in Figure 3B. We found that, as expected, B1a cells expressed levels of SOCS3 much higher than the levels expressed by B2 cells. Importantly, we found that among B1a cells, the large majority of SOCS3 transcripts were located specifically within the $\mathrm{CD} 25^{+}$B1a fraction. Thus, a select subset of B1a cells that expresses the IL-2R $\alpha$ chain (CD25) and contains elevated levels of activated signaling intermediates 


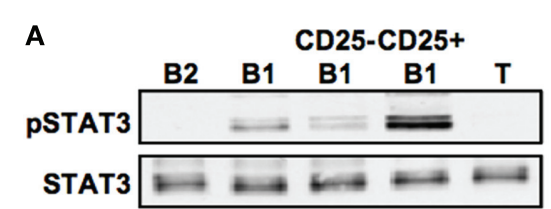

$\mathbf{B}$

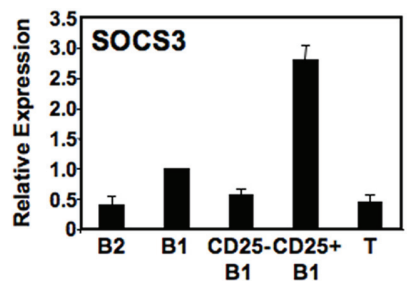

FIGURE 3 | CD25+ B1a cells display elevated levels of phosphorylated tyrosine705 STAT3. Five lymphocyte populations were sort-purified: splenic follicular B2 cells ("B2"), peritoneal B1a cells ("B1"), CD25peritoneal B1a cells ("CD25- B1"), CD25+ peritoneal B1a cells ("CD25+ $B 1$ "), and splenic T cells ("T"). (A) Protein extracts were prepared from each of these populations and immunoblotted for expression of pTyr705STAT3 ("pSTAT3"). Blots were stripped and reprobed for expression of total STAT3 as a loading control. Representative results from one of two comparable experiments are shown. (B) RNA was prepared from each of these populations, reverse transcribed, and evaluated for expression of SOCS3 by real-time PCR, normalized to $\beta 2$-microglobulin. Expression by each population relative to peritoneal B1a cells is shown as the mean of six experiments with lines indicating the SE of the means.

also expresses the bulk of phosphorylated, functionally active STAT3 that was previously known to be upregulated in B1a cells as a whole.

However, it is unlikely that CD25 and pSTAT3 are directly connected, inasmuch as expression of CD25 was not accompanied by expression of CD122 (IL-2R $\beta$ chain) transcript (Figure 4) or surface protein (data not shown), which were essentially absent in $\mathrm{B} 1$ and B2 cell populations, as contrasted with activated $\mathrm{T}$ cells. Further, there was no response of $\mathrm{CD} 25^{+}$B1a cells to IL-2 as shown by the failure of IL-2 to produce tyrosine phosphorylation of STAT5 (data not shown). These results indicate that CD25 marks a pTyr705STAT3-containing subset of peritoneal B1 cells but does not function as a complete, cytokine-responsive receptor.

\section{CD25 $^{+}$B1a CELLS EXPRESS LIF RECEPTOR}

The association between CD25 expression and phosphorylated STAT3, combined with the lack of a direct mechanism connecting the two, raises the possibility that another STAT3-active cytokine receptor segregates with $\mathrm{CD} 25^{+}$B1a cells. In previous work with embryonic stem cells, LIF-induced self-renewal was shown to depend on STAT3 (Niwa et al., 1998); inasmuch as B1 cells display the property of self-renewal along with activated STAT3, we considered the possibility that LIF and LIFR might play a role in B1a pSTAT3 expression. Inasmuch as immunofluorescent reagents are not available to detect murine LIFR, we first examined sortpurified B cell populations for LIFR gene expression by real-time PCR. Results are shown in Figure 5A. We found that B1a cells expressed LIFR transcripts whereas B2 cells did not. Importantly, we found that the level of LIFR gene expression was much greater

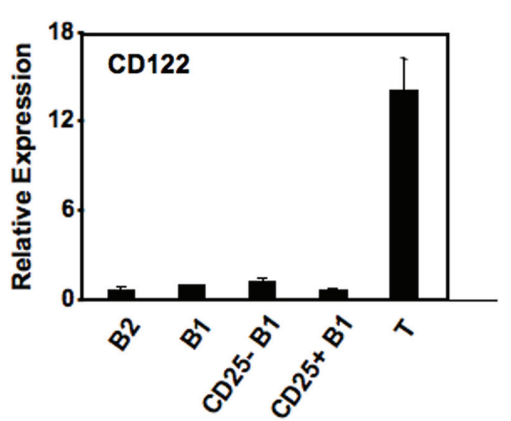

FIGURE 4 | CD25 expression on a subset of B1a cells is not accompanied by expression of CD122. Five lymphocyte populations were sort-purified: splenic follicular B2 cells ("B2"), peritoneal B1a cells ("B1"), CD25- peritoneal B1a cells ("CD25- B1"), CD25+ peritoneal B1a cells ("CD25+ B1"), and splenic T cells ("T"). B cell populations were unstimulated whereas T cells were stimulated by ConA at $5 \mu \mathrm{g} / \mathrm{ml}$ for 2 days. RNA was prepared, reverse transcribed, and evaluated for expression of CD122 by real-time PCR, normalized to $\beta 2$-microglobulin. Expression by each population relative to peritoneal B1a cells is shown as the mean of six experiments with lines indicating the SE of the means.

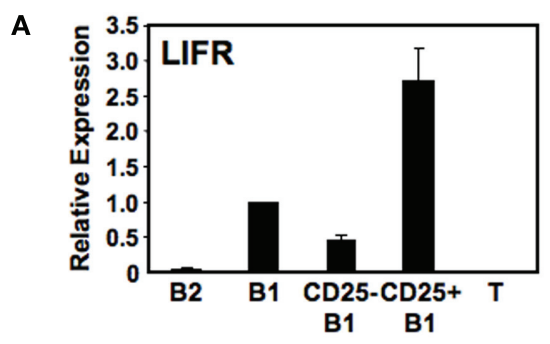

B

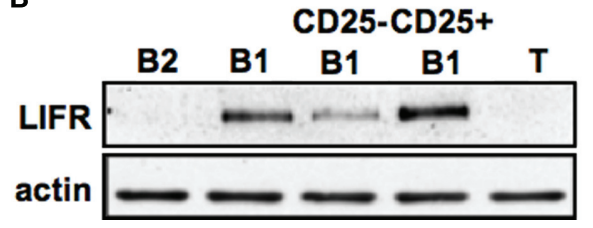

FIGURE 5 | CD25+ ${ }^{+}$B1a cells express LIF receptor (LIFR). Five lymphocyte populations were sort-purified: splenic follicular B2 cells ("B2"), peritoneal B1a cells ("B1"), CD25- peritoneal B1a cells ("CD25- B1"), CD25+ peritoneal B1a cells ("CD25+ B1"), and splenic T cells ("T"). (A) RNA was prepared from each of these populations, reverse transcribed, and evaluated for expression of LIFR by real-time PCR, normalized to $\beta 2$-microglobulin. Expression by each population relative to peritoneal B1a cells is shown as the mean of six experiments with lines indicating the SE of the means, with the exception of splenic T cells for which $n=3$. (B) Protein extracts were prepared from each of these populations and immunoblotted for expression of "LIFR." Blots were stripped and reprobed for expression of total beta actin (actin) as a loading control. Representative results from one of three comparable experiments are shown.

in $\mathrm{CD} 25^{+}$B1a cells than in $\mathrm{CD} 25^{-}$B1a cells. To verify the relative enrichment of CD25 ${ }^{+}$B1a cells for LIFR expression, we evaluated LIFR protein expression by Western blotting. Results are shown in Figure 5B. Much like LIFR gene expression, we found that B1a cells expressed LIFR protein whereas B2 cells (and T cells) did not; 


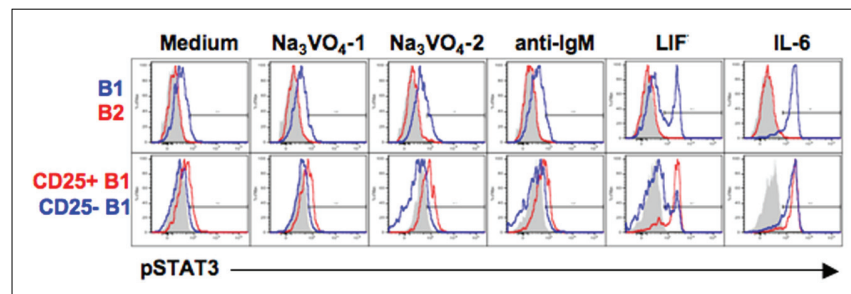

FIGURE 6 | CD25+ B1a cells respond to LIF. Four populations of B cells were sort-purified: peritoneal B1a cells ("B1" in blue in upper panel), splenic follicular B2 cells ("B2" in red in upper panels), CD25+ peritoneal $\mathrm{B} 1 \mathrm{a}$ cells ("CD25+ B1" in red in lower panels), and CD25- peritoneal B1a cells ("CD25- B1" in blue in lower panels). B cells were cultured in medium alone ("Medium"), with $\mathrm{Na}_{3} \mathrm{VO}_{4}$ at $10 \mathrm{mM}$ for 1 or $2 \mathrm{~min}$, as indicated, with $\mathrm{F}\left(a b^{\prime}\right)_{2}$ fragments of goat anti-mouse $\operatorname{lgM}$ at $15 \mu \mathrm{g} / \mathrm{ml}$ for $4 \mathrm{~min}$ ("anti-IgM"), with recombinant LIF at $10 \mathrm{ng} / \mathrm{ml}$ for $5 \mathrm{~min}$, or with recombinant IL-6 at $10 \mathrm{ng} / \mathrm{ml}$ for $5 \mathrm{~min}$. Cells were then harvested, fixed, permeabilized, and examined for intracellular tyrosine phosphorylated STAT3 ("pSTAT3") by phosphoflow analysis. Isotype control antibody staining is displayed in gray. Representative results from one of three comparable experiments are shown. The displayed results were obtained at the same time as the results shown in Figure 2A.

importantly, we found that the level of LIFR was much greater in $\mathrm{CD} 25^{+}$B1a cells than in CD25- B1a cells. Thus, LIFR segregates with CD25 expression among peritoneal B1a cells, much like phosphorylated STAT3 and activated signaling intermediates.

\section{CD25+ B1a CELLS RESPOND TO LIF}

The CD25+ B1a cell LIFR might mediate STAT3 phosphorylation; on the other hand, the failure of CD25 to mediate IL-2 signaling in these cells raises the possibility that LIFR might be similarly indolent. To address this issue, we examined the phosphorylation status of STAT3 after LIF treatment in sort-purified B cell populations by phosphoflow analysis. Results are shown in Figure 6. We found that, at baseline and as expected, B1a cells contained more pTyr705STAT3 than B2 cells, and CD25 ${ }^{+}$B1a cells contained more pSTAT3 than $\mathrm{CD} 25^{-}$B1a cells; these relationships were both accentuated by treatment with $\mathrm{Na}_{3} \mathrm{VO}_{4}$. Importantly, we found that addition of LIF (in the absence of $\mathrm{Na}_{3} \mathrm{VO}_{4}$ ) produced a marked increase in pSTAT3 in B1a cells (but not in B2 cells), resulting in a bimodal distribution, suggesting the presence of responsive and non-responsive populations. Further examination of separated $\mathrm{CD} 25^{+}$and $\mathrm{CD} 25^{-}$B1a cells revealed that the increase in pSTAT3 induced by LIF occurred predominantly within the $\mathrm{CD} 25^{+}$B1a population. As a control, IL- 6 treatment of these B cell populations produced an increase in pSTAT3 that was equally shared by the $\mathrm{CD}_{2} 5^{+}$and $\mathrm{CD} 25^{-}$Bla populations. Thus, LIF specifically affects LIFR-expressing CD25 ${ }^{+}$B1a cells indicating that the LIFR is functional in this Bla subset.

\section{DISCUSSION}

The work described herein identifies a novel subset of B1 cells that expresses the high affinity IL-2 receptor $\alpha$ chain, CD25. Despite comprising only one-fifth of peritoneal B1a cells, the $\mathrm{CD} 25^{+}$population accounts for two key characteristics previously attributed to the whole population of peritoneal B1a cells: constitutive expression of pSTAT3 (along with attendant expression of
SOCS3); and, continual activation of signaling intermediates. It is unclear why CD25 $5^{-}$B1a cells are deficient in these features, but this finding raises the possibility that CD25+ and CD25- B1a cells differ in origin, development, BCR specificity, and/or function.

One function in particular that differs between $\mathrm{CD} 25^{+}$and CD25- B1a cells relates to LIF signaling, the receptor for which is here shown to be expressed preferentially by CD $25^{+} \mathrm{B} 1$ a cells. LIFR expression to our knowledge has not been previously reported on any B cell subset. Further, LIFR on CD25 ${ }^{+}$B1a cells constitutes a functioning receptor that responds to LIF with an increase in STAT3 phosphorylation. This suggests a role for LIF in the baseline level of pSTAT3 previously shown to be elevated in B1a cells and here shown to segregate with $\mathrm{CD} 25^{+}$B1a cells. Although the net result of LIFR and pSTAT3 expression by $\mathrm{CD} 25^{+} \mathrm{B} 1 \mathrm{a}$ cells remains uncertain, these molecules have been reported to contribute powerfully to processes of activation, expansion, differentiation, and immunoregulation (Taupin et al., 1998; Bowman et al., 2000; Bromberg and Darnell, 2000; Calo et al., 2003; Dimitriou et al., 2008), implying a distinct physiology for CD25 ${ }^{+}$ as opposed to CD25- B1a cells. In particular, LIF and STAT3 promote self-renewal and pluripotency of embryonic stem cells (Niwa et al., 1998; Cartwright et al., 2005), suggesting that B1a cell self-renewal may be focused on the $\mathrm{CD} 25^{+}$population that is activated, presumably, as a result of self-antigen recognition. It may be speculated that this would promote the maintenance of a population of Bla cells specialized for production of immunoglobulin that serves to homeostatically bind and dispose of cellular debris (Binder and Silverman, 2005). Of note, SOCS3 inhibits pSTAT3 and LIFR signaling (Naka et al., 1997; Starr et al., 1997; Auernhammer and Melmed, 2001; Yoshimura et al., 2007), suggesting a complex interplay among these components that in the context of $B$ cells takes place solely within a minor subset of B1a cells that expresses CD25.

Although LIFR expression correlates with signaling in response to LIF, the index marker for the CD25 ${ }^{+}$B1a subset, CD25 (IL-2Ra), does not constitute a complete receptor and does not mediate signaling in response to IL-2 as it does in activated B2 cells, due to the lack of CD122 (IL-2R $\beta$; Muraguchi et al., 1985; Minami et al., 1993). On the other hand, CD25 expression appears to reflect activation in B1a cells as it does in $\mathrm{B} 2$ cells, because $\mathrm{CD} 25^{+}$ B1a cells preferentially manifest continual activation of signaling mediators, as previously described for Bla cells in general, and because interference with signalosome mediators produces a rapid decline in CD25 expression. Of note, however, the stability of CD25 expression over long periods of time in vivo after adoptive transfer (unpublished observations) suggests that CD25 does not reflect a temporary stage of, or transient event in, B1a cells, but rather corresponds to a chronic condition of activation. Our previous work suggests that continual activation of signaling mediators in Bla cells is BCR-driven, presumably on the basis of antigen, or self-antigen, recognition. In this scenario a consequence of continual signaling, upregulation of CD25, would also be determined by BCR antigen specificity, which as an unchanging characteristic is consistent with CD25 persistence. Analysis of CD25 ${ }^{+}$and CD25B1a immunoglobulins showed a trend toward more N-less (and thus more germline like) sequences in the former (unpublished observations); however, this did not reach the level of significance 
and it will be necessary to examine antigen recognition rather than antibody structure to elucidate the origin of Bla continual signaling and CD25 expression. Of note, no difference in spontaneous antibody secretion has been noted between $\mathrm{CD} 25^{+}$and $\mathrm{CD} 25^{-}$ B1 cells (unpublished observations).

As a positive control for activation of signaling intermediates $\mathrm{B}$ cell antigen receptors were polyclonally crosslinked with antiIgM. In B1a cells, this led to an increase in pSyk and pPLC $\gamma 2$, that was more marked in $\mathrm{CD} 25^{+}$as compared to $\mathrm{CD} 25^{-} \mathrm{B} 1 \mathrm{a}$ cells. These results recapitulate our earlier finding (Morris and Rothstein, 1994) that BCR crosslinking in B1 cells yields normal induced phosphorylation of PLC $\gamma 2$ that, however, fails to produce full enzymatic activation. In light of the failure of BCR crosslinking in $\mathrm{B} 1$ cells to produce NF- $\kappa \mathrm{B}$ activation or mitogenic stimulation, phosphorylation of signaling intermediates as shown here and elsewhere (Wong et al., 2002) emphasizes that

\section{REFERENCES}

Alugupalli, K. R., Leong, J. M., Woodland, R. T., Muramatsu, M., Honjo, T., and Gerstein, R. M. (2004). B1b lymphocytes confer $\mathrm{T}$ cellindependent long-lasting immunity. Immunity 21, 379-390.

Arnold, L. W., Pennell, C. A., McCray, S. K., and Clarke, S. H. (1994). Development of B-1 cells: segregation of phosphatidylcholine-specific B cells to the B-1 population occurs after immunoglobulin gene expression. $J$. Exp. Med. 179, 1585-1595.

Auernhammer, C. J., and Melmed, S. (2001). The central role of SOCS-3 in integrating the neuroimmunoendocrine interface. J. Clin. Invest. 108, 1735-1740.

Baumgarth, N., Herman, O. C., Jager, G. C., Brown, L. E., Herzenberg, L. A., and Chen, J. (2000). B-1 and B2 cell-derived immunoglobulin $\mathrm{M}$ antibodies are nonredundant components of the protective response to influenza virus infection. J. Exp. Med. 192, 271-280.

Benedict, C. L., and Kearney, J. F. (1999). Increased junctional diversity in fetal B cells results in a loss of protective anti-phosphorylcholine antibodies in adult mice. Immunity 10 , 607-617.

Berland, R., and Wortis, H. H. (2002). Origins and functions of B-1 cells with notes on the role of CD5. Annu. Rev. Immunol. 20, 253-300.

Binder, C. J., and Silverman, G. J. (2005). Natural antibodies and the autoimmunity of atherosclerosis. Springer Semin. Immunopathol. 26, 385-404.

Boes, M., Prodeus, A. P., Schmidt, T., Carroll, M. C., and Chen, J. (1998). A critical role of natural immunoglobulin $\mathrm{M}$ in immediate defense against systemic bacterial infection. J. Exp. Med. 188, 2381-2386.
Bowman, T., Garcia, R., Turkson, J., and Jove, R. (2000). STATs in oncogenesis. Oncogene 19, 2474-2488.

Briles, D. E., Nahm, M., Schroer, K., Davie, J., Baker, P., Kearney, J., and Barletta, R. (1981). Antiphosphocholine antibodies found in normal mouse serum are protective against intravenous infection with type 3 Streptococcus pneumoniae. J. Exp. Med. 153, 694-705.

Bromberg, J., and Darnell, J. E., Jr. (2000). The role of STATs in transcriptional control and their impact on cellular function. Oncogene 19, 2468-2473.

Brunn, G. J., Falls, E. L., Nilson, A. E., and Abraham, R. T. (1995). Proteintyrosine kinase-dependent activation of STAT transcription factors in interleukin-2- or interleukin-4stimulated T lymphocytes. J. Biol. Chem. 270, 11628-11635.

Bruun, C., Heding, P. Eo., Ronn, S. G., Frobose, H., Rhodes, C. J., MandrupPoulsen, T., and Billestrup, N. (2009). Suppressor of cytokine signalling-3 inhibits Tumor necrosis factor-alpha induced apoptosis and signalling in beta cells. Mol. Cell. Endocrinol. 311, 32-38.

Calo, V., Migliavacca, M., Bazan, V., Macaluso, M., Buscemi, M., Gebbia, N., and Russo, A. (2003). STAT proteins: from normal control of cellular events to tumorigenesis. J. Cell. Physiol. 197, 157-168.

Cartwright, P., McLean, C., Sheppard, A., Rivett, D., Jones, K., and Dalton, S. (2005). LIF/STAT3 controls ES cell self-renewal and pluripotency by a Myc-dependent mechanism. Development 132, 885-896.

Casola, S., Otipoby, K. L., Alimzhanov, M., Humme, S., Uyttersprot, N., Kutok, J. L., Carroll, M. C., and Rajewsky, K. (2004). B cell receptor

$\mathrm{BCR}$ signaling in $\mathrm{B} 1$ cells is not indolent, just different. The recent report that SOCS3 can interfere with NF- $\kappa$ B activation (Bruun et al., 2009) suggests another explanation for the early termination of BCR signaling in B1 cells (Rothstein and Kolber, 1988a,b; Morris and Rothstein, 1993).

In sum, $\mathrm{CD} 25^{+} \mathrm{B} 1 \mathrm{a}$ cells represent a minor $\mathrm{B} 1$ cell population that preferentially embodies the known $\mathrm{B} 1$ cell characteristics of continual signaling and activated STAT3, and is here shown to be the sole B cell population that expresses LIFR and responds to LIF. The latter may contribute to constitutive expression of pSTAT3 in B1 cells.

\section{ACKNOWLEDGMENTS}

This work was supported by United States Public Health Service grants AI029690 and AI060896 awarded to Thomas L. Rothstein by the National Institutes of Health.

signal strength determines B cell fate. Nat. Immunol. 5, 317-327.

Cong, Y. Z., Rabin, E., and Wortis, H. H. (1991). Treatment of murine CD5$B$ cells with anti-Ig, but not LPS, induces surface CD5: two B-cell activation pathways. Int. Immunol. 3 , 467-476.

Dimitriou, I. D., Clemenza, L., Scotter, A. J., Chen, G., Guerra, F. M., and Rottapel, R. (2008). Putting out the fire: coordinated suppression of the innate and adaptive immune systems by SOCS1 and SOCS3 proteins. Immunol. Rev. 224, 265-283.

Duber, S., Hafner, M., Krey, M., Lienenklaus, S., Roy, B., Hobeika, E., Reth, M., Buch, T., Waisman, A., Kretschmer, K., and Weiss, S. (2009). Induction of B-cell development in adult mice reveals the ability of bone marrow to produce B-1a cells. Blood 114, 4960-4967.

Fischer, G. M., Solt, L. A., Hastings, W. D., Yang, K., Gerstein, R. M., Nikolajczyk, B. S., Clarke, S. H., and Rothstein, T. L. (2001). Splenic and peritoneal B-1 cells differ in terms of transcriptional and proliferative features that separate peritoneal B-1 from splenic B-2 cells. Cell. Immunol. 213, 62-71.

Frances, R., Tumang, J. R., Kaku, H., Gurdak, S. M., and Rothstein, T. L. (2006). B-1 cells express transgelin 2: unexpected lymphocyte expression of a smooth muscle protein identified by proteomic analysis of peritoneal B-1 cells. Mol. Immunol. 43, 2124-2129.

Frances, R., Tumang, J. R., and Rothstein, T. L. (2007). Extreme skewing of annexin II and S100A6 expression identified by proteomic analysis of peritoneal B-1 cells. Int. Immunol. $19,59-65$.
Frank, D. A., Robertson, M. J., Bonni, A., Ritz, J., and Greenberg, M. E. (1995). Interleukin 2 signaling involves the phosphorylation of Stat proteins. Proc. Natl.Acad. Sci. U.S.A. 92, 7779 7783.

Gu, H., Forster, I., and Rajewsky, K. (1990). Sequence homologies, N sequence insertion and $\mathrm{JH}$ gene utilization in VHDJH joining: implications for the joining mechanism and the ontogenetic timing of Lyl B cell and $\mathrm{B}-\mathrm{CLL}$ progenitor generation. ЕМBO J. 9, 2133-2140.

Hamilton, A. M., Lehuen, A., and Kearney, J. F. (1994). Immunofluorescence analysis of B- 1 cell ontogeny in the mouse. Int. Immunol. 6, 355-361.

Hardy, R. R. (2006). B-1 B cell development. J. Immunol. 177, 2749-2754.

Hardy, R. R., Carmack, C. E., Shinton, S. A., Riblet, R. J., and Hayakawa, K. (1989). A single VH gene is utilized predominantly in antiBrMRBC hybridomas derived from purified Ly-1 B cells. Definition of the VH11 family. J. Immunol. 142, 3643-3651.

Hardy, R. R., and Hayakawa, K. (2001). B cell development pathways. Annu. Rev. Immunol. 19, 595-621.

Hayakawa, K., Hardy, R. R., and Herzenberg, L. A. (1986). Peritoneal Ly-1 B cells: genetic control, autoantibody production, increased lambda light chain expression. Eur. J. Immunol. 16, 450-456.

Hayakawa, K., Hardy, R. R., Parks, D. R., and Herzenberg, L. A. (1983). The "Ly-1 B" cell subpopulation in normal immunodefective, and autoimmune mice. J. Exp. Med. 157, 202-218.

Herzenberg, L.A. (2000). B-1 cells: the lineage question revisited. Immunol. Rev. 175, 9-22. 
Holodick, N. E., Repetny, K., Zhong, X., and Rothstein, T. L. (2009a). Adult BM generates $\mathrm{CD} 5$ ( B1 cells containing abundant $\mathrm{N}$-region additions. Eur. J. Immunol. 39, 2383-2394.

Holodick, N. E., Tumang, J. R., and Rothstein, T. L. (2009b). Continual signaling is responsible for constitutive ERK phosphorylation in B-1a cells. Mol. Immunol. 46, 3029-3036.

Holodick, N. E., Tumang, J. R., and Rothstein, T. L. (2010). Immunoglobulin secretion by $\mathrm{B} 1$ cells: differential intensity and interferon response factor 4-dependence of spontaneous IgM secretion by peritoneal and splenic B1 cells. Eur. J. Immunol. 40, 3007-3016.

Kantor, A. B., Stall, A. M., Adams, S., and Herzenberg, L. A. (1992). Differential development of progenitor activity for three B-cell lineages. Proc. Natl. Acad. Sci. U.S.A. 89, 33203324.

Kantor, A. B., Stall, A. M., Adams, S., Watanabe, K., and Herzenberg, L. A. (1995). De novo development and self-replenishment of B cells. Int. Immunol. 7, 55-68.

Karras, J. G., Wang, Z., Huo, L., Howard, R. G., Frank, D. A., and Rothstein, T. L. (1997). Signal transducer and activator of transcription-3 (STAT3) is constitutively activated in normal, self-renewing B-1 cells but only inducibly expressed in conventional B lymphocytes. J. Exp. Med. 185, 1035-1042.

Klein, U., Casola, S., Cattoretti, G., Shen, Q., Lia, M., Mo, T., Ludwig, T., Rajewsky, K., and DallaFavera, R. (2006). Transcription factor IRF4 controls plasma cell differentiation and class-switch recombination. Nat. Immunol. 7, 773-782.

Krutzik, P. O., and Nolan, G. P. (2006). Fluorescent cell barcoding in flow cytometry allows highthroughput drug screening and signaling profiling. Nat. Methods 3, 361-368.

Lalor, P. A., Herzenberg, L. A., Adams, S., and Stall, A. M. (1989). Feedback regulation of murine Ly-1 B cell development. Eur. J. Immunol. 19, 507-513.

Lin, K. I., Tunyaplin, C., and Calame, K. (2003). Transcriptional regulatory cascades controlling plasma cell differentiation. Immunol. Rev. 194, 19-28.

Minami, Y., Kono, T., Miyazaki, T., and Taniguchi, T. (1993). The IL-2 receptor complex: its structure, function, and target genes. Annu. Rev. Immunol. 11, 245-268.

Montecino-Rodriguez, E., Leathers, H., and Dorshkind, K. (2006).
Identification of a B-1 B cellspecified progenitor. Nat. Immunol. 7, 293-301.

Morris, D. L., and Rothstein, T. L. (1993). Abnormal transcription factor induction through the surface immunoglobulin M receptor of B1 lymphocytes. J. Exp. Med. 177, 857-861.

Morris, D. L., and Rothstein, T. L. (1994). Decreased surface IgM receptor-mediated activation of phospholipase C gamma 2 in B-1 lymphocytes. Int. Immunol. 6 , 1011-1016.

Muraguchi, A., Kehrl, J. H., Longo, D. L., Volkman, D. J., Smith, K. A., and Fauci, A. S. (1985). Interleukin 2 receptors on human B cells. Implications for the role of interleukin 2 in human B cell function. J. Exp. Med. 161, 181-197.

Murphy, T. P., Kolber, D. L., and Rothstein, T. L. (1990). Elevated expression of Pgp-1 (Ly-24) by murine peritoneal B lymphocytes. Eur. J. Immunol. 20, 1137-1142.

Naka, T., Narazaki, M., Hirata, M., Matsumoto, T., Minamoto, S., Aono, A., Nishimoto, N., Kajita, T., Taga, T., Yoshizaki, K., Akira, S., and Kishimoto, T. (1997). Structure and function of a new STAT-induced STAT inhibitor. Nature 387, 924-929.

Nielsen, M., Svejgaard, A., Skov, S., and Odum, N. (1994). Interleukin2 induces tyrosine phosphorylation and nuclear translocation of stat 3 in human $\mathrm{T}$ lymphocytes. Eur. J. Immunol. 24, 3082-3086.

Niwa, H., Burdon, T., Chambers, I., and Smith, A. (1998). Self-renewal of pluripotent embryonic stem cells is mediated via activation of STAT3. Genes Dev. 12, 2048-2060.

Ochsenbein, A. F., Fehr, T., Lutz, C., Suter, M., Brombacher, F., Hengartner, H., and Zinkernagel, R. M. (1999). Control of early viral and bacterial distribution and disease by natural antibodies. Science 286 , 2156-2159.

Pennell, C. A., Mercolino, T. J., Grdina, T. A., Arnold, L. W., Haughton, G., and Clarke, S. H. (1989). Biased immunoglobulin variable region gene expression by Ly-1 B cells due to clonal selection. Eur. J. Immunol. 19, 1289-1295.

Rolink, A., Grawunder, U., Winkler, T. H., Karasuyama, H., and Melchers, F. (1994). IL-2 receptor alpha chain (CD25, TAC) expression defines a crucial stage in pre-B cell development. Int. Immunol. 6, 1257-1264.

Rothstein, T. L. (2002). Cutting edge commentary: two B-1 or not to be one. J. Immunol. 168, 4257-4261.
Rothstein, T. L., and Kolber, D. L. (1988a). Anti-Ig antibody inhibits the phorbol ester-induced stimulation of peritoneal B cells. J. Immunol. 141, 4089-4093.

Rothstein, T. L., and Kolber, D. L. (1988b). Peritoneal B cells respond to phorbol esters in the absence of co- mitogen. J. Immunol. 140, 2880-2885.

Savitsky, D., and Calame, K. (2006). B-1 B lymphocytes require Blimp-1 for immunoglobulin secretion. J. Exp. Med. 203, 2305-2314.

Starr, R., Willson, T. A., Viney, E. M., Murray, L. J., Rayner, J. R., Jenkins, B. J., Gonda, T. J., Alexander W. S., Metcalf, D., Nicola, N. A. and Hilton, D. J. (1997). A family of cytokine-inducible inhibitors of signalling. Nature 387, 917-921.

Su, S. D., Ward, M. M., Apicella, M. A., and Ward, R. E. (1991). The primary $\mathrm{B}$ cell response to the $\mathrm{O} /$ core region of bacterial lipopolysaccharide is restricted to the Ly-1 lineage. J. Immunol. 146, 327-331.

Tanguay, D. A., Colarusso, T. P. Doughty, C., Pavlovic-Ewers, S. Rothstein, T. L., and Chiles, T. C. (2001). Cutting edge: differential signaling requirements for activation of assembled cyclin D3-cdk4 complexes in B-1 and B-2 lymphocyte subsets. J. Immunol. 166, 42734277.

Tanguay, D. A., Colarusso, T. P., Pavlovic, S., Irigoyen, M., Howard, R. G. Bartek, J., Chiles, T. C., and Rothstein, T. L. (1999). Early induction of cyclin D2 expression in phorbol ester-responsive B-1 lymphocytes. J. Exp. Med. 189, 1685-1690.

Taupin, J. L., Pitard, V., Dechanet, J., Miossec, V., Gualde, N., and Moreau, J. F. (1998). Leukemia inhibitory factor: part of a large ingathering family. Int. Rev. Immunol. 16, 397-426.

Tumang, J. R., Frances, R., Yeo, S. G. and Rothstein, T. L. (2005). Spontaneously Ig-secreting B- 1 cells violate the accepted paradigm for expression of differentiation-associated transcription factors. J. Immunol 174, 3173-3177.

Tumang, J. R., Hastings, W. D., Bai, C. and Rothstein, T. L. (2004). Peritoneal and splenic B-1 cells are separable by phenotypic, functional, and transcriptomic characteristics. Eur. J. Immunol. 34, 2158-2167.

Tumang, J. R., Owyang, A., Andjelic, S., Jin, Z., Hardy, R. R., Liou, M. L., and Liou, H. C. (1998). c-Rel is essential for B lymphocyte survival and cell cycle progression. Eur. J. Immunol. 28, 4299-4312.
Wang, H., and Clarke, S. H. (2004). Regulation of B-cell development by antibody specificity. Curr. Opin. Immunol. 16, 246-250.

Wang, Z., Morris, D. L., and Rothstein, T. L. (1995). Constitutive and inducible levels of egr-1 and c-myc early growth response gene expression in self-renewing B-1 lymphocytes. Cell. Immunol. 162, 309-314.

Wong, S. C., Chew, W. K., Tan, J. E., Melendez, A. J., Francis, F., and Lam, K. P. (2002). Peritoneal CD5( B-1 cells have signaling properties similar to tolerant B cells. J. Biol. Chem. 277, 30707-30715.

Wortis, H. H., and Berland, R. (2001). Cutting edge commentary: origins of B-1 cells. J. Immunol. 166, 21632166

Yoshimura, A., Naka, T., and Kubo, M. (2007). SOCS proteins, cytokine signalling and immune regulation. Nat. Rev. Immunol. 7, 454-465.

Zhong, X., Gao, W., Degauque, N., Bai, C., Lu, Y., Kenny, J., Oukka, M., Strom, T. B., and Rothstein, T. L. (2007a). Reciprocal generation of Th1/Th17 and $\mathrm{T}(\mathrm{reg})$ cells by $\mathrm{B} 1$ and B2 B cells. Eur. J. Immunol. 37, 2400-2404.

Zhong, X., Tumang, J. R., Gao, W., Bai, C., and Rothstein, T. L. (2007b). PDL2 expression extends beyond dendritic cells/macrophages to $\mathrm{B} 1$ cells enriched for $\mathrm{V}(\mathrm{H}) 11 / \mathrm{V}(\mathrm{H}) 12$ and phosphatidylcholine binding. Eur. J. Immunol. 37, 2405-2410.

Conflict of Interest Statement: The authors declare that the research was conducted in the absence of any commercial or financial relationships that could be construed as a potential conflict of interest.

Received: 02 November 2010; paper pending published: 30 November 2010; accepted: 21 February 2011; published online: 21 March 2011.

Citation: Tumang JR, Holodick NE, Vizconde TC, Kaku H, Francés R and Rothstein TL (2011) A CD25- positive population of activated B1 cells expresses LIFR and responds to LIF. Front. Immun. 2:6. doi:10.3389/fimmu.2011.00006

This article was submitted to Frontiers in B Cell Biology, a specialty of Frontiers in Immunology.

Copyright () 2011 Tumang, Holodick, Vizconde, Kaku, Francés and Rothstein. This is an open-access article subject to an exclusive license agreement between the authors and Frontiers Media SA which permits unrestricted use, distribution, and reproduction in any medium, provided the original authors and source are credited. 